\title{
In What Ways Can Objects of Utility Be Considered as Appropriate Study for Art Education?: An Inquiry Grounded in British and American Contexts, 1832-1988
}

\author{
Paul Sproll
}

In my teaching of art I have become increasingly intrigued by why it is that certain objects gain a place in art education curricula while others do not achieve much visibility, and indeed may be neglected altogether. It is unlikely, for example, that a chair is the focus of study in most art programs. Yet I contend that while this object may "appear" to be too mundane to warrant serious study, it has much to reveal in itself and indeed as a class of objects is capable of achieving poetic status. This is the context of my research question.

My research is a development of my master's thesis A Study of British Government Involvement in Links Between Art and Manufacture 1835-1864: The Genesis of a Systematic Program of Art Education in England. This inquiry unearthed a number of issues, political, social and economic, which had, and continue to have their counterparts in art education this side of the Atlantic. The common strand that intrigued me the most, was the relationship between art education and the commercially manufactured object. This continues to be a central focus of my research. The purpose of the study is to identify the ways in which objects of utility can be considered as appropriate study for art education. My research strategy consists of three interrelated components:

1) An historical inquiry designed to trace the influence of political, social, and economic interventionism in Britain and America and its impact on the content of art education programs.

2) A philosophical, sociological,and cultural examination of the utilitarian objects as a communicative and expressive phenomenon. The chair is used as an exemplar for objects of utility and as a vehicle to document the relationship between the everyday world and the art world.

3) The development of a theoretical framework for making connections between common everyday objects of utility and "fine art".

There exists a multitude of reasons why objects come to achieve symbolic status, though often the motives surrounding their elevation within art education curricula remains somewhat obscure. The presentation of objects deemed to be appropriate study for art education occurs by no means in an arbitrary manner. This in itself, is more than sufficient reason, I contend, for those involved in art education to have cause to examine not only an

Working Papers in Art Education 1989 - 1990 
object's intrinsic qualities and meanings, but also to become more attentive of their participation in a process which appends "value" to those "exemplars" introduced to students. The promotion of certain objects at the expense of others in the field of art education is a result of a melange of social, political, and economic dynamics which ultimately casts the curriculum mould into which only "approved" content is poured. One purpose of this inquiry is then to unravel the relationships that exist between art education and those forces which contribute to dictating and shaping its content. The dynamics of such relationships in the curriculum-content equation can be far too easily overlooked, as if art education were in some unique way impervious to the societal contexts in which it operates. This investigation is therefore grounded in the premise that the subject's role and content is inevitably a reflection of orchestrated social forces.

The history of art education in Britain and America is replete with parallel instances where curriculum content has been determined by an agenda that extended beyond purely educational concerns. Thistlewood (1986) suggests in the case of Britain that "the first system of compulsory art education devised and implemented in the mid-nineteenth century was justified primarily on grounds of social [in Victorian times, synonymous with "commercial'] significance" (p. 71). The social significance of art education was not lost on those most intimately concerned with the development of American industry also, as an extract from the Paris Universal Exposition, 1867: Reports of the United States Commissioners states that "the importance of art education as applied to manufactures is so obvious as to need no enforcement in this age" (p. 247). The content of an art education curriculum was then, to be determined primarily by the economic needs of the state, and the development of a student's aesthetic sensibilities appears to have been only of secondary consideration. The commercially manufactured object would be used as the yardstick with which to measure the health of a nation's commercial enterprise, while its design and availability to the public would be seen as a measure of a nation's taste.

Arthur Efland (1987) in his paper "Art Education in the Twentieth Century: A History of Ideas" provides a quotation from Paul Goodman's book Growing up Absurd stating that "the use of history. . . is to rescue from oblivion the lost causes of the past. History is especially important when those lost causes haunt us in the present as unfinished business" (p. 1). Such is the case with the history of art education in Britain and America. Art education curricula in Britain over at least the last two decades have moved quite distinctly away from the notion of being concerned with the "expressive arts", to what has been dubbed an "art and design rationale". And what we begin to see is a pattern of curriculum intervention not too dissimilar to those enacted in the nineteenth century. Now, as then, Ministers of the Crown utter according to Steers (1987) "demands for greater accountability; and for the curriculum to be more 'relevant;' relevant perhaps to the Government's perception of national economic health rather than the educational health of the nation". In America in 1985, Congress charged the National Endowment

Working Papers in Art Education 1989 - 1990 
for the Arts to produce a report on the state of arts education; "this was the second such request in history. The first, more than a hundred years ago. . . completed by Isaac Edwards Clarke in 1884" (NEA, 1988, p. 1). British and American nineteenth-century governmental reports were born out of concerns of economic inferiority, and it was hoped that art education could play a role in reversing the tide. A century later, echoes of these earlier concerns are resurrected in the 1988 NEA report The Arts in America: A Report to the President and to Congress which agrees that "insecurity about our ability to compete in world markets has reappeared" (p. 1). Yet this report is adamant that "this time Congress has made it clear that cultural, not economic, welfare is the concern" (p. 1). It is somewhat difficult to accept this rather philanthropic tone at face value, when in their Five-Year Planning Document: 1990-1994 the NEA suggests that "American business needs to take advantage of its native design resources to help restore our competitive edge" (p. 141). This document further accepts that the design field would benefit from "improved visual literacy, appreciation of architecture and design inculcated through American primary and secondary systems" (p. 141).

Clark and Zimmerman (1989) see growing evidence in recently published British art education books of proposals for curriculum reform very similar to those being propounded in the U.S.. They state that "although these two contexts differ, questions being asked about what should be taught in art classrooms, and how, are quite similar. Surprisingly answers to these questions are more alike than different" (p. 55). Though "contexts" may indeed differ, history clearly reveals that content of art education curricula on both sides of the Atlantic has been determined by varying degrees by commercial motives. In Britain the ascendancy of design education within art education programs and its proliferation in schools is quite certainly the result of a curriculum interventionist's agenda which seeks commercial, economic and vocational benefits from the study of art. While design has become increasingly at the core of art education programs in Britain, there are no such signs at present in American schools. Statistics furnished by the National Center for Statistics in 1984 indicate that design accounted for only $4 \%$ of high school course offerings in the U.S. during $1981-82$, and that a mere $0.5 \%$ of seniors enrolled in design courses during their 4 years. While such auspicious bodies as the National Endowment for the Arts call for the inclusion of design as a legitimate artform and a component of arts curricula, there appears to be little evidence of solid proposals for implementation strategies. Indeed, there appear to be almost irreconcilable philosophical differences between some of the interested parties. While the NEA argues a case for the study of "I.M. Pei's Christian Science Center in Boston (mid-1970s); Battery Park City (mid-1980s, still in progress), Mies Van der Rohe's Barcelona Chair, (1929); [and] Levi Strauss' 501 Jeans" (NEA, 1988, pp. 205-206), not all art educators would agree that sufficient justification exists for such objects to be considered appropriate study for art education. The reluctance to admit such objects into the arena of art education dramatically reduces our spheres of influence in enhancing the aesthetic sensibilities of our students.

Working Papers in Art Education 1989 - 1990 
Herschell Chipp (1968), in his book Theories of Modern Art, includes a statement by the painter Fernand Leger, which encapsulates the damage caused by some art educators' all too narrow concept of the nature of art:

Many individuals would be sensitive to the beauty of common objects without artistic intention, if the preconceived notion of the objet d'art were not a bandage over their eyes. Bad visual education is the cause of this tendency (p. 277).

The bandage of which Leger speaks is the adherence by some to a theory of art which treats according to Lanier (1963) "the visual arts as if the fine arts of the museum and gallery are clearly superior as a group of objects to others abundantly available in our environment". The belief is still very prevalent, that a certain class of objects exists as a group apart from those things which support the basic functions of human existence. The adoption of this theory elevates such things within society, recognizing them to be the pinnacle of human artistic endeavour. This act has the effect of seriously limiting what can be considered appropriate material for study in art education. While it can be argued that any object has the potential to be considered aesthetic, the utility of an object appears to be a barrier (in the eyes of some art educators) to the perception of certain objects as having the potential to be works of art. The promotion and study of only the non-utilitarian then assumes there is no aesthetic motive in the practical domain. This is an assumption which is increasingly being challenged as the notions of what constitutes art undergo revision. Monroe Beardsley (1981) indeed suggests that "if we can weigh the value of a Mondrian painting, why not the top of a Kleenex box? .. . a chair?" (p. 61). Art education's seeming reluctance to adopt a more all-embracing attitude to the products of human endeavour severely narrows possible fields of study and effectively polarizes the content of art education programs. This polarization separates art from life, and in doing so maintains a hierarchy with fine art at its head.

It seems paradoxical that while the art museum and gallery, the very repositories of art education content, have increasingly begun to exhibit utilitarian objects, we as art educators have by-and-large chosen to select only fine art as the content for our courses. The continuation of such a policy does however have its challengers: Feldman (1970), Chapman (1978), and Lanier (1987) all plead for enlargement in the scope of art curricula, and charge the art educator with the responsibility of introducing students to "the potency of visual form and structure in all avenues of everyday life: (Barkan, 1965, p. 70). The exclusion of what I contend is a significant range of objects from art education curricula effectively denies the possibility of introducing students to the concept proposed by Marantz (1972) that "objects can be touchstones for some kind of human experience". George Kubler (1962) in The Shape of Time: Remarks on the History of Things similarly supports the notion that objects have the potential to transmit evidence of the human experience. But all too often he argues, individuals prize objects either for their utility or for their aesthetic qualities. The extremes of these elements in

Working Papers in Art Education 1989 - 1990 
perception are, however, he suggests "only in our imagination, human products always incorporate both utility and art in varying mixtures, and no object is conceivable without the admixture of both" (p. 14). In considering objects of utility as works of art one is confronted with a tension between physical and aesthetic natures. And it is the existence of this tension that makes the utilitarian object a more than suitable candidate for study in a visual arts program. Challenging our students to look afresh at a whole range of everyday things will most certainly involve them in the performance of perceptual cartwheels. Harold Osborne (1984) warns that the difficulty of such intellectual gymnastics should not be minimized as "to perceive coherently in this way is more difficult. . . because it cuts across deeply ingrained habits of practical life" (p. 32).

While the focus of my inquiry at this time is centered on issues of a theoretical nature, the study clearly has curriculum ramifications, and though I am not yet prepared to outline specific implementation strategies, there is manifest justification for major art education curriculum reform. Current curriculum practice in art education does not address the available panorama of humanmade objects; and in failing to do so our students are presented with a narrow vision of what art is, and are, themselves, therefore ill-prepared to meet the demands of their kaleidoscopic world. The curriculum I envisage seeks to make connections between the art room and the world-at-large. The object of utility is a vehicle for poetry which is "waiting to be heard and seen in education in many different parts of the curriculum" (Baynes, 1982, p. 114). This, I foresee is the challenge for art educators in both Britain and America.

\section{References}

Barkan, M. (1965). Curriculum and the teaching of art. In J. J. Hausman (Ed.). Report of the commission on art education. Washington, D.C.: National Art Education Association.

Baynes, K. (1982). Beyond design education. Journal of Art and Design Education, 1 (1), 105-114.

Beardsley, M. (1981). Aesthetics: Problems in the philosophy of criticism (2nd ed.). Indianapolis: Hackett Publishing.

Chapman, L. H. (1978). Approaches to art in education. New York: Harcourt Brace Jovanovich.

Chipp, H. B. (Ed.). (1968). Theories of modern art: A source book by artists and critics. Berkley: University of California Press.

Clark, G., \& Zimmerman, E. (1988). Five British art education books. Art Education, 42 (1), 55-57. 
Efland, A. (1987). Art education in the twentieth century: A history of ideas. Unpublished manuscript.

Feldman, E. B. (1970). Becoming human through art: Aesthetic experience in school. Englewood Cliffs, New Jersey: Prentice Hall.

Kubler, G. (1962). The shape of time: Remarks on the history of things. New Haven: Yale University Press.

Lanier, V. (1983). Beyond aesthetic education. Art Education, 36 (6), 31-37.

Lanier, V. (1987). $A^{\star} R^{\star} T$, a friendly alternative to D.B.A.E. Art Education, 4 (5), 46-52.

Marantz, K. (1972). Visual education and the human experience. In M. M. Krug (Ed.). What will be taught in the next decade. Itasca, Illinois: Peacock Publishers.

National Endowment for the Arts (1988). Five-Year planning document: 1990-1994. Washington D.C.: U.S. Government Printing Office.

National Endowment for the Arts (1988). The arts in America: A report to the President and to Congress. Washington D.C.: U.S. Government Printing Office.

National Endowment for the Arts (1988). Towards civilization: A report on arts education. Washington D.C.: U.S. Government Printing Office.

Osborne, H. (1984). The cultivation of sensibility in art education. Journal of Philosophy of Education, 18 (1), 31-40.

Sproll, P. A. (1988). A study of British involvement in links between art and manufacture 1835-1864: The genesis of a systematic programme of art education in England. Unpublished master's thesis. The Ohio State University.

Steers, J. (1987). Current issues in art and design education: Resistance and the freedom to fly. Journal of Art and Design, 6 (1), 13-26.

Thistlewood, D. (1986). Social significance of British art education 1850-1950. Journal of Aesthetic Education, 20 (1), 71-83.

Working Papers in Art Education 1989 - 1990 